This is a non-peer reviewed EarthArXiv preprint that has been submitted for publication in Land Use Policy. As a function of the peer-reviewing process that this manuscript will undergo, its structure and content may change. If accepted, the final version of this manuscript will be available via the 'Peer-reviewed Publication DOI' link on the right-hand side of this webpage. Please feel free to contact any of the authors; we welcome feedback.

\title{
Analysis of off-site economic costs induced by runoff and soil erosion: example of two areas in the northwestern European loess belt for the last two decades (Normandy, France)
}

$\underline{\text { Edouard Patault }}{ }^{1,2}$, Jérôme Ledun ${ }^{3}$, Valentin Landemaine ${ }^{4}$, Arnaud Soulignac ${ }^{5}$, Jean-Baptiste Richet ${ }^{3}$, Matthieu Fournier ${ }^{2}$, Jean-François Ouvry ${ }^{3}$, Olivier Cerdan ${ }^{4}$, Benoit Laignel ${ }^{1}$

${ }^{1}$ Normandie UNIV, UNIROUEN, Service Responsabilité Sociétale et Développement Durable, Rouen, France

${ }^{2}$ Normandie UNIV, UNIROUEN, UNICAEN, CNRS, M2C, FED-SCALE, Rouen, France

${ }^{3}$ AREAS, 2 avenue Foch, F-76460 Saint-Valéry-en-Caux, France

${ }^{4}$ BRGM, 3 avenue Claude Guillemin, BP6009, F-45060 Orléans Cedex 2, France

${ }^{5}$ BRGM, 1039 rue de Pinville, F-34000 Montpellier, France

Corresponding author: Edouard Patault (edouard.patault1@univ-rouen.fr)

Highlights

- Off-site economic costs of runoff and erosion were quantified through an analysis of public expenditures for the last two decades.

- The total avoidance damages cost ranged from 375 to $485 \mathrm{M} €$.

- The total social damages cost reached $236 \mathrm{M} €$.

- The mean cost per capita was estimated to 9.1 and $21.6 € \mathrm{yr}^{-1}$ for the Eure and the SeineMaritime respectively.

\section{Abstract}

While soil erosion and runoff physical aspects are widely addressed in the literature, few studies have focused on the economical dimension. However, it is essential to consider this dimension to conduct appropriate land use management policies. Erosion and runoff are known to result into onsite and off-site impacts. A fully exhaustive analysis of erosion and runoff economic costs may be 
difficult and ambitious due to the availability of the data and a lack of actual knowledge. In this study, we chose to analyze the main off-site economic costs induced by these processes in two specific areas located in the northwestern European loess belt (Normandy, France). We quantified avoidance and social damages over the last 25 years through a global and retrospective analysis of financial databases provided by regional or local authorities (water agencies, departmental councils, reinsurance, drinking water companies, transport infrastructures managers) and existing literature review. Our analysis suggested that over that period, the total damages cost ranged from 611 to $721 \mathrm{M€}$. Off-site avoidance damage costs accounted for almost $2 / 3$ of the total expenditure. In the Seine-Maritime area, the mean cost was evaluated to $21.6 € \mathrm{yr}^{-1} \mathrm{cap}^{-1}$ and to $9.1 € \mathrm{yr}^{-1} \mathrm{cap}^{-1}$ in the Eure area. Even if we tried to be as exhaustive as possible some off-site economic costs remained unknown. It appeared that more research is necessary for the scientific community to get a full picture of off-site economic costs induced by erosion and runoff.

\section{Keywords}

Erosion; runoff; off-site impacts; costs; damages; loess belt

\section{Introduction}

Soil erosion is recognized as one of the most pressing environmental problem of our time, decreasing agricultural productivity, degrading ecosystem function, and amplifying hydrogeological risks (UN FAO, 2019). Since several years, scientific studies have essentially focused on the physical aspect of this phenomenon over the economic aspect. As reported by Panagos et al. (2018), a simple Google Scholar search reported that only $0.4 \%$ of the publications relevant to soil erosion focus on the economical dimension. However, soil erosion can generate multiple economic costs, which can be divided into two main categories depending on the affected territories. Economic costs due to on-site impacts that directly affect farmland through a loss of fertile topsoil and a consequent decrease of productivity (de la Rosa et al., 2000; Bakker et al., 2004; Lal, 2010). Economic costs generated by offsite impacts which can include in-stream problems of water quality and quantity, siltation of dams, 
accelerated runoff leading to localized flooding, degradation of drinking water (Clark, 1996). Over the past years, much attention has been drawn to on-site costs. In the US, Pimentel et al. (1995) estimated to 27 billion US $\$ \mathrm{yr}^{-1}$ the on-site costs generated by soil erosion. In Europe, Panagos et al. (2018) estimated to 1.25 billion $€$ the cost of crop productivity loss due to soil erosion using direct cost evaluation. In Java, Indonesia, the loss of crop productivity was estimated to $340-406 \mathrm{M} \mathrm{yr}^{-1}$ (Magrath \& Arens, 1989). In USA, the loss of nutrient and organic matter ranged from $5 \mathrm{M} \$$ to 20 billion $\$$ per year (see review of Santos Telles et al., 2011). However, the off-site costs might be substantial and can exceed the on-site costs by a factor 10 even though a large part of the off-site costs cannot be quantified (Görlach et al., 2004). To the best of our knowledge, few attempts had been made to quantify the off-site costs generated by soil erosion and runoff. Pimentel et al. (1995) estimated the off-site costs for the US to be about 17 billion US $\$ \mathrm{yr}^{-1}$. Evans (1996) estimated from local authority data that the external costs of soil erosion to roads and property to be $14 \mathrm{Mf}$ in England and Wales. Pretty et al. (2000) estimated the off-site costs of soil erosion for the UK at $14 \mathrm{Mf}$ in 1996 (range 8-30 Mf for 1990-1996). In central Belgium, the societal cost of muddy floods was evaluated to 16-172 M€ each year by Evrard et al. (2007). In Aisne (France), muddy floods led to a mean damage of $118 € \mathrm{ha}^{-1}$ $\mathrm{yr}^{-1}$ during a 10-year period (Evrard et al., 2010). In southern England (Brighton and Breaky Bottom), the total cost of erosion and runoff events for insurers in 2000-2001 was estimated to 1.45 M€ (Evrard et al., 2010). Thirty years ago, Holmes (1988) estimated the off-site impact of soil erosion on the water treatment industry to be close to $458-661 \mathrm{M}$ US $\$ \mathrm{yr}^{-1}$. Few studies also tried to evaluate the damage avoidance costs generated by public policy to reduce erosion and runoff impacts. For example, the economic assessment of erosion control measures has been evaluated in the UK through a cost-benefit analysis (Posthumus et al., 2015). It can therefore be seen that economic costs of on-site and off-site impacts of runoff and soil erosion can be very important, but also highly variable. In fact, total economic cost will mostly depend on the societal and biophysical characteristic of the studied environment, and the level of ambition fixed by public policies to reduce the impacts of erosion and runoff on their respective territories. While scientific community attempted to evaluate on-site and 
off-site costs of soil erosion at global scale (UN FAO, 2019), a detailed study of the economic impact can probably only be done by collecting data obtained by local or regional studies (Dorren et al., 2004). Country like France can be particularly challenging because it presents a wide range of different erosive contexts induced by diversity in soil types, climate, geomorphology, land use, and agricultural systems. In Normandy, runoff and erosion problems have reached an alarming level both in terms of rate and of geographical extent (Souadi et al., 2000; Le Bissonnais et al., 2002; Cerdan et al., 2010). Catastrophic flooding and mudflows still occur regularly and the pollution of drinking water sources by sediments was recurrent in the last decades (Nebbache et al., 2001; Souchère et al., 2003; Evrard et al., 2010; Boardman et al., 2019). Since 2000s, a regional public policy was instituted to reduce soil erosion and runoff impacts (Fullen et al., 2006; Martin et al., 2010). This public policy led to: (i) the construction of hard hydraulic structures (dam, retention pond) to store water runoff, and soft hydraulic structures (fascine, hedge, etc.) to reduce input of sediment by mudflows, (ii) the development of preventive action on the field (animation, technical support), and (iii) the creation of water treatment schemes to reduce turbidity. While the farmer pays on-site impacts of erosion, the off-site impacts are generally financed by local taxes (Martin et al., 2014). The whole public policy deployed in the last decades suggested that a high amount of money had been spent to avoid runoff and erosion impacts on these areas. In parallel, a high financial support was spent due to off-site impacts on public infrastructures (flooding and mudflows on private properties, roads, turbidity at water treatment plant, etc.). Therefore, the purpose of this study was to quantify the main off-site economical costs induced by soil erosion and runoff in two areas sensitives to erosion and runoff and located in the northwestern European loess belt (Seine-Maritime and Eure department, Normandy, France). To reach that point, off-site economic impacts (societal and avoidance damages) of erosion and runoff were evaluated through a global and retrospective analysis of all financial databases available since the last decades (public funders, reinsurance, transport infrastructures, regional health authority, and drinking water companies) and scientific literature review allowing the definition of economic indicators related to runoff and erosion processes. 


\section{Study area}

The study area is the northeastern part of the Normandy region in France (ex-UpperNormandy) which is composed of two main departments (Seine-Maritime and Eure; $12318 \mathrm{~km}^{2}$ ). The two areas are located in the northwestern European loess belt. The climate is temperate oceanic, and the mean temperature is $11^{\circ} \mathrm{C}$ with low amplitude oscillations. Even if rain events are rather spread during the year, the mean yearly rainfall shows significant spatial disparities. From 1981 to 2010 , the mean yearly rainfall ranges from $503 \mathrm{~mm}$ in the southern part of the Eure department to $1110 \mathrm{~mm}$ in the western part of the Seine-Maritime department (SIGES Seine-Normandie, 2013). The geology is composed of the chalk from the Cretaceous period and is overlaid by loamy soils. Altitudes range from 0 to $250 \mathrm{~m} \mathrm{NGF}$ in the southern part of the Eure department. The two departments include 1420 municipalities (745 in Seine-Maritime and 675 in Eure). The area is highly developed, accounting for 1856221 inhabitants (1 254378 in Seine-Maritime and 601843 in Eure; INSEE 2017), 2126 km of railways, and 29006 km of roads. In 2015, the GDP per inhabitant was $26400 €$, slightly below the French average (30 $600 €)$ (Eurostat, 2017). Arable land is the most important land use covering 68.8\% of the total surface (Fig. 1A). The lithological context explained the predominance of arable lands: the study area is part of the northwestern European loess belt. It is composed of medium-textured soils (silty or loamy soils), recognized for their excellent agronomic performance. Unfortunately, these soils are sensitive to crusting and therefore characterized by high erodibility (Panagos et al., 2014). Rates of soil erosion are low to moderate in this area (0.5-10 $\mathrm{t} \mathrm{ha}^{-1} \mathrm{yr}^{-1}$; Cerdan et al., 2010) but a high density of muddy flooding is observed (10-20 km-2; Boardman et al., 2019). Flooding and mudflow are the main off-site impacts frequently observed on the territory (Fig. 2). In recent year, a public policy has emerged in Seine-Maritime and Eure department to reduce erosion and runoff impacts (Fullen et al., 2006, Martin et al., 2010). It was mainly driven by the EU Water Framework Directive requiring nations to improve waterways to good "ecological status" (European Parliament, 2000). As illustrated in Figure $1 B$, the public policy led to the building of 1809 hard hydraulic infrastructures (mainly dam and retention pond with a total water storage capacity of 7 million $\mathrm{m}^{3}$ ) and 3000 soft hydraulic 
infrastructures (fascine, hedge, grass strip, agro-forestry, leach field, gabion, pond, ditch,

133 embankment). Main off-site impacts observed on the territory are: (i) failure of drinking water supply

134 due to high level of turbidity, and (ii) damages to buildings and public infrastructures. The high level of

135 turbidity in drinking water can be mainly explained by a high-density of sinkholes, leading to a rapid

136 transfer of sediment by runoff and erosion to drinking water intakes (Nebbache et al., 2001; Fig. 1C).
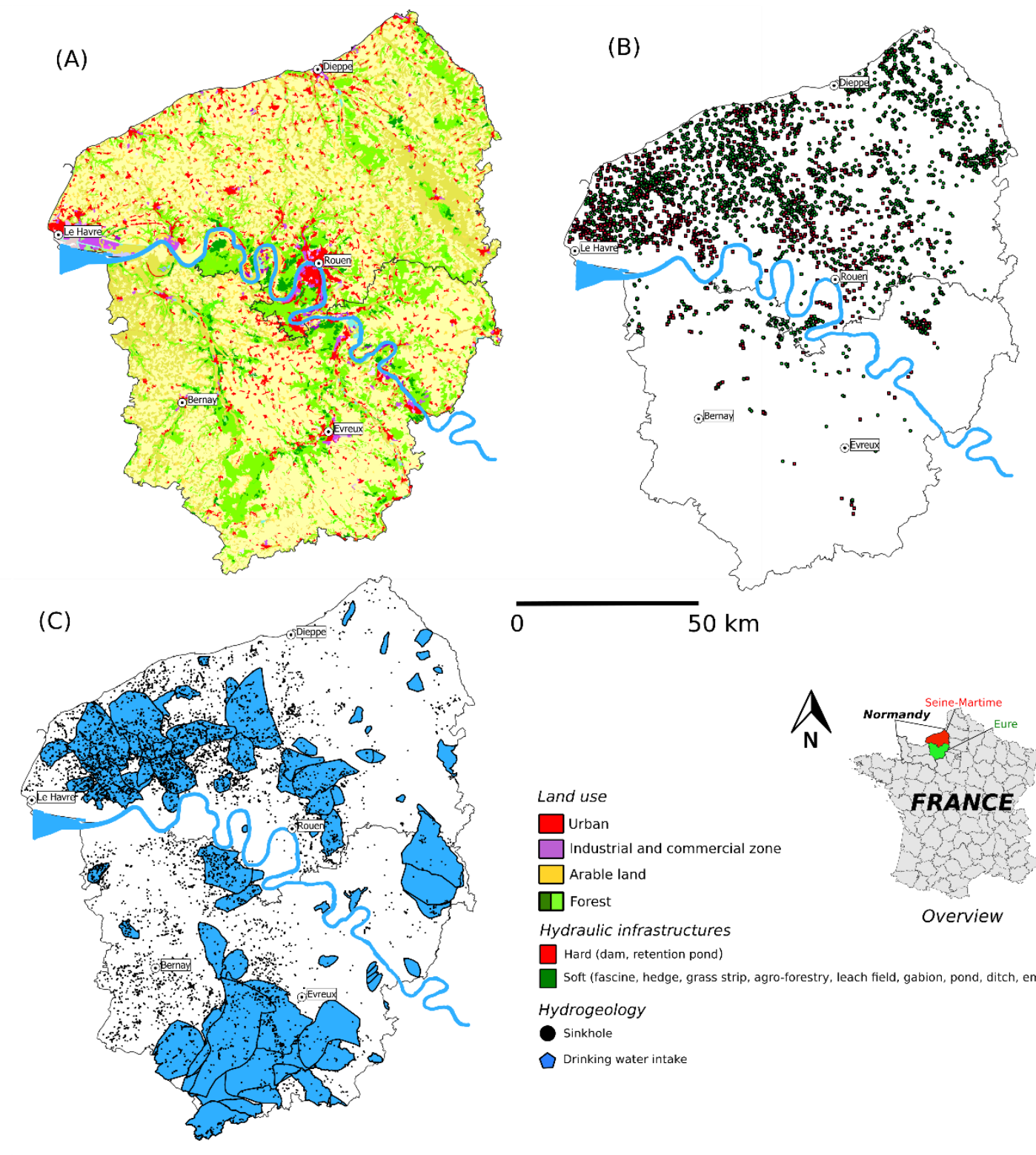

$\overline{0} 50 \mathrm{~km}$

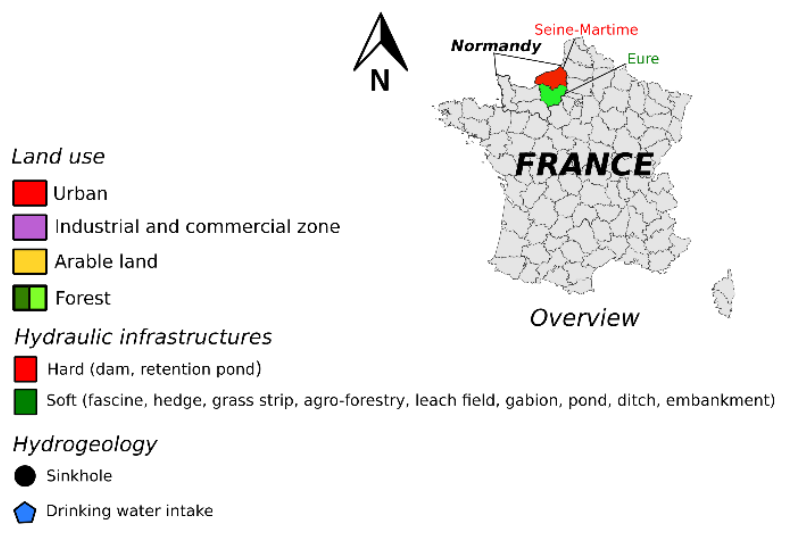

Figure 1: (A) Major land use on the study area (data: Corine Land Cover 2012 ${ }^{1}$ ), (B) Hydraulic infrastructures (data: DB

\footnotetext{
${ }^{1}$ https://www.data.gouv.fr/fr/datasets/corine-land-cover-occupation-des-sols-en-france/

2 http://bdcastor.fr/

${ }^{3}$ http://sigessn.brgm.fr/spip.php?article116
} 


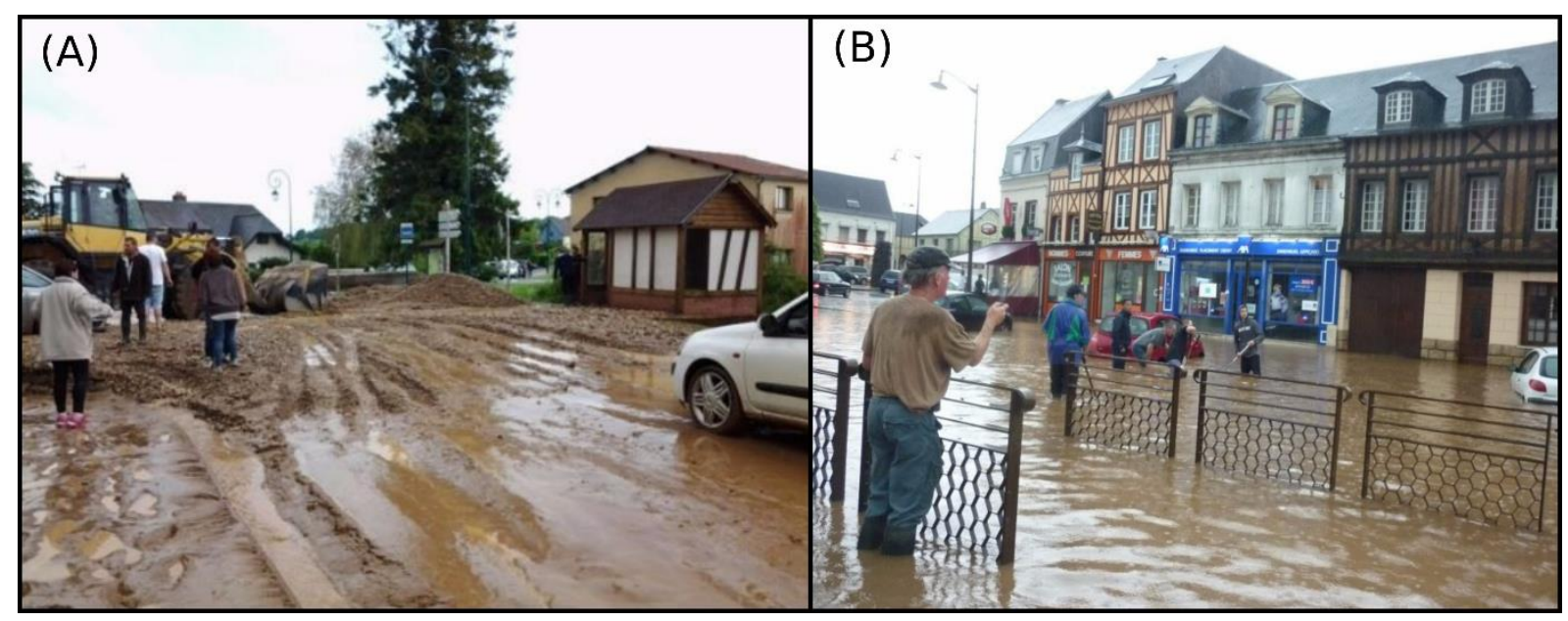

Figure 2: (A) Grumesnil, Seine-Maritime, mudflows, May 2016, and (B) Buchy, Seine-Maritime, flooding, May 2016.

\section{Input data and methods}

\subsection{Transport infrastructures}

\subsection{Road network}

The data were collected from the departmental road services of the two departments. Data included economic cost for departmental road only, excluding highway, national and municipal roads.

Departmental roads extend over a linear of $10941 \mathrm{~km}$. The road network management is divided into 8 agencies and 56 operating centers. The operations following mudflows or floods consist in: (i) the cleaning of basins, ditches, and pipes, (ii) pavement or hydraulic structures repairs, and (iii) pavement cleaning. These interventions necessarily induced economic costs that can be carried out either under contract or subcontracted to companies.

\subsection{Railway network}

The data were collected from the French railway company "SNCF" who manage the rail network in the Normandy region. The data provided a financial summary of expenditures incurred on minor incidents related to floods, mudflows, and landslides from 2012 to 2018 . We draw the reader's attention to the fact that the data provided by the SNCF does not consider exceptional events identified and announced by the French meteorological service "MétéoFrance", which are then economically charged to a national financial scheme attached to the event. Some infrastructures 
presenting a high risk of erosion and known to the SNCF require special surveillance. Their staff regularly visit these structures (on a regular, one-off or on-call basis), but the associated economic costs are listed in a specific account and indistinguishable. Finally, mudflows on railway network may be responsible for delays and remedial works but the economic costs are aggregated in a maintenance envelope, which is again indistinguishable.

\subsection{Insured assets}

In France, since the introduction of the compensation scheme for natural disasters in 1982, the "Caisse Centrale de Réassurance" (CCR) provides access to unlimited state guaranteed reinsurance cover for natural disasters in France to those insurance companies requiring this protection (CCR, 2017). In parallel, as the secretary of the Inter-Ministerial Commission for Natural Disasters, CCR maintains a database (CatNat aka "Catastrophe Naturelle") in which are recorded all decrees recognizing the occurrence of a natural disaster. Over the time, CCR has collected data from insurance companies it reinsures under bilateral agreements to understand better France's exposure to natural disasters, covering insured risks (by location or communes) and claims incurred. According to the analysis of the French insurance market exposure to floods by CCR, insured flood losses are generally located inside the floodplains (45\%), outside the floodplains (45\%), and another $10 \%$ is due to sea surge flood and groundwater rise (Moncoulon et al., 2014). This database contains up to $60 \%$ of market data in terms of claims incurred (71 cedants). In this study, we focus on specific disaster types: flooding and mudflows. For the Seine-Maritime and the Eure departments, the database contains over 1377 entries starting in 1998. The CCR's extrapolated claims costs are calculated when claims are loaded. Claims are linked to the CatNat database, ordered by peril and date of occurrence. CCR's cost extrapolation methodology is as follows: the sum of claims from a cedant is compared to annual accounting data and cost data by events received by CCR. Then for each financial year, the market share of the cedants providing the data is calculated. The number of cases and amount of claims received per fiscal year are extrapolated using an extrapolation coefficient. Thus, for each claim, the following elements are reported: the municipality, the date, the initial cost, the extrapolated cost, the number of extrapolated 
claims. The natural disaster guarantee provides for the coverage of direct material damage "net of deductibles" caused only to the insured property. Operating losses resulting from direct damage are also covered. However, the database does not consider the cost of damage to uninsured property. To overcome this limit, an assessment of actual damage can be estimated by multiplying the extrapolated cost by 1.5 (CEPRI, 2019, personal communication).

\subsection{Supply of drinking water}

Turbidity in karstic environment like ex Upper-Normandy is a natural phenomenon linked to operational activities like pumping (Hanin, 2011), resuspension of sediment in karstic storages and conduits (Masséi et al., 2003; Valdes et al., 2005), as well as because of rapid transfer (via sinkholes) on the surface catchment induced by heavy rainfall events (Valdes et al., 2006; El Janyani et al., 2014). Turbidity is a significant challenge to the operation of a drinking water company and can affect its ability to continue to supply potable water (Stevenson and Bravo, 2019). According to the French law and based on the decree $2001-1220$ of 20 December 2001, operators of water distribution systems must ensure that the water they distribute meets drinking water standards. The limit set out in the drinking water quality is 1 NTU (Nephelometric Turbidity Unit) at the point of distribution. In case of heavy rainfall events, few drinking water suppliers cannot reach that threshold. This may be explained by: (i) a persistence of a high turbidity level $(<12-24 \mathrm{~h}$ ), (ii) a water treatment process not effective enough to filter the turbidity peak, and (iii) a lack of water treatment process or emergency interconnection. When the drinking water quality is not sufficient at the point of distribution, the regional health authority ("Agence Régionale de Santé"; ARS) issues an alert to prohibit the clean water drinking and distributes bottled water to the population (1.5 L/day/capita). The prohibition of clean water drinking induces three main economic costs: (i) bottled water purchase, (ii) information to the public, and (iii) logistic for the distribution. In Seine-Maritime and Eure, 407 prohibitions of clean water drinking were recorded since 1992. The number of inhabitants impacted, and the duration, is known for $60 \%$ of the records. For the remaining $40 \%$ (exclusively in Seine-Maritime), the duration was missing 
and evaluated, based on the mean duration of the fully detailed records in this department (10.5 days).

The total bottled water purchase (BWP; $€$ exc. tax) is calculated based on the following equation:

$$
B W P_{\text {total }}=\sum_{i=1}^{n} B W P_{i}=\sum_{i=1}^{n} N_{i} * \Delta t_{i} * A * B
$$

With $N_{i}$ the number of inhabitants impacted for the record $i, \Delta t_{i}$ the duration (in days) of the prohibition alert, $A$ is a constant equal to 1.5 liter, and B is the mean price of a bottled water $(0.0986$ $€$ exc. tax. $\mathrm{L}^{-1}$; bulk purchasing) considering feedback from the "Le Havre Seine Métropole" (LHSM). Based on two fully detailed study cases from LHSM, and ARS (Mansotte, 1998), information and logistic costs were evaluated respectively to 0.648 and $0.74 €$ exc. tax per inhabitant per record.

\subsection{Regional authorities' financial databases}

Between 2000 and 2017, seven public institutions funded the public policy against runoff and erosion impacts: (i) the Seine-Normandie Water Agency (AESN), (ii) the Seine-Maritime department, (iii) the Eure department, (iv) the Haute-Normandie Regional Council (CRHN), (v) the European Regional Development Fund (FEDER), (vi) the French state, and (vii) the parliamentary reservation. Database from the FEDER, the French state, and the parliamentary reservation were not available and, hence, were not analyzed in this study. However, the total costs associated to each project were available in the other databases. By checking the financial monitoring from the four selected institutions, it is possible to determine the total cost of a project, and the portion eligible for public subvention. In the framework of the public policy against erosion and runoff, only eligible amount was kept for further analysis. Unfortunately, funding can be manifold on a given project, as illustrated in Figure S1. To estimate the overall volume of public investment, data were crossed and visually checked to avoid double-counting. We also categorized the investments in nine categories (including different sub-categories). Investments were separated based on two simple objectives, the one specific to erosion and runoff and the other specific to turbidity. Some investments relied to both objectives. For 
investments specific to erosion and runoff, we used all data provided by the public funders. For

234 investments specific to turbidity in drinking water, the AESN database was sufficient, because on this problematic, it is the AESN that always fund the projects. For the first category (i.e. investments specific to erosion/runoff), AESN's database was used as a reference and redundancies were checked in the three other databases. For the CRHN, only $9.17 \%$ of the total investment was not redundant with the AESN database and kept for further analysis. For the Eure department, 131 projects were not cofunded by the AESN and kept for the analysis. For the Seine-department, the redundancy was difficult to evaluate, so two implicit assumptions were made: (i) AESN and Seine-Maritime always co-funded project, so we take the maximum investment of a project from one or another, and (ii) both institutions never co-founded a project and their respective investment can be summed. Cross-validation with data from a local river basin committee ("Syndicat Mixte du Bassin Versant de l'Austreberthe et du Saffimbec") suggested that priority must be given to the second hypothesis. For the second category (i.e. investments specific to turbidity in drinking water) investments were considered carefully. Indeed, actions can have several motivations, and investments can be motivated by a desire to protect drinking water against other types of pollution (nitrates, pesticides, PAHs, etc.). Empirical ratios were defined to extract the part of the overall investment for drinking water specific to the turbidity. Based on expert knowledge and discussion with public funders, we applied the following ratios on three main categories to extract the relative part induced only by turbidity in drinking water: $50 \%$ on investments relating to animation on the field; $70 \%$ on investments relating to water potabilization and drinking water quantitative management.

\subsection{Erosion control measures and maintenance}

The overall erosion control measures against runoff, erosion, and turbidity to drinking water in the Seine-Maritime and Eure department (see details in Fig. 1B), is recorded by the "Association de recherche sur le Ruissellement, l'Erosion et l'Aménagement du Sol' (AREAS) in an open-access database called CASTOR ("Connaissance des Aménagements de preservation des Sols et des Terres, et des Ouvrages de ralentissement des Ruissellements"; http://bdcastor.fr/). For the purposes of the 
study, we extracted from the database all infrastructures located in the studied area $(n=4809)$. To assess the volume of investment related to the maintenance of theses infrastructures, a first screening was necessary. We extracted only functional hydraulic infrastructures that need recurrent maintenance, and for which the year of construction and the dimensions were given. We discarded the steel gabions and timber cribs, for which the dimensions were not available, or the annual maintenance cost could not be determined. The final database that is used to evaluate the economic cost of hydraulic infrastructures maintenance includes 3946 entries (Table 1). For each entry, the maintenance cost was evaluated based on the year of construction, the dimensions, and the annual maintenance cost. The annual maintenance cost was assessed through literature review and feedbacks from building owner's projects. The total economic cost of the overall maintenance was assessed considering inflation. The annual maintenance costs are corrected for inflation based on the analysis of the evolution of the cost of production indices for public works (ICP-TP) from 1998 to 2018 (deflator = 100 in 2018; Fig. S1). Between 1998 and 2018, the average annual variation is thus estimated at 2.1\%. This average annual variation was applied to the previous years until 1931 (date of creation of the oldest dam listed in the BD CASTOR). Annual maintenance cost for each erosion control measures were then corrected and aggregated over time.

Table 1: Synthesis of existing erosion control measures (number and overall dimensions) on the Seine-Maritime and Eure department, extracted from the Castor database ( $\mathrm{Im}=$ linear meters).

\begin{tabular}{|l|r|r|r|r|}
\hline & \multicolumn{1}{|c|}{$\begin{array}{c}\text { Seine- } \\
\text { Maritime }\end{array}$} & \multicolumn{2}{c|}{ Eure } & \multicolumn{2}{c|}{$\begin{array}{c}\text { Seine- } \\
\text { Maritime }\end{array}$} \\
\hline \multicolumn{1}{|c|}{ Erosion control measure } & \multicolumn{2}{|c|}{ Number $(n)$} & \multicolumn{2}{c|}{ Dimensions } \\
\hline Dam/Retention pond & 697 & 76 & $5330133 \mathrm{~m}^{3}$ & $209652 \mathrm{~m}^{3}$ \\
\hline Leach field & 9 & 1 & $203 \mathrm{ha}$ & $4 \mathrm{ha}$ \\
\hline Fascine & 636 & 30 & $18210 \mathrm{Im}$ & $641 \mathrm{Im}$ \\
\hline Hedge & 1003 & 30 & $201751 \mathrm{Im}$ & $4433 \mathrm{Im}$ \\
\hline Pond & 795 & 44 & $1110364 \mathrm{~m}^{3}$ & $35007 \mathrm{~m}^{3}$ \\
\hline Ditch & 314 & 57 & $88230 \mathrm{Im}$ & $11246 \mathrm{Im}$ \\
\hline Embankment & 113 & 38 & $16660 \mathrm{Im}$ & $7447 \mathrm{Im}$ \\
\hline Grass strip & 79 & 24 & $64 \mathrm{ha}$ & $13 \mathrm{ha}$ \\
\hline
\end{tabular}




\section{Results and Discussion}

\subsection{Off-site avoidance damage cost}

\subsubsection{Overall investment}

The total investment costs had been evaluated through the analysis of all regional authorities' financial database available since 2000 (Table 2). The analysis suggests that 4307 projects were financially supported to reduce runoff, erosion, and turbidity impacts on the Eure and Seine-Maritime department. The overall volume of public investments ranged from 300 to $410 \mathrm{M} €$ exc. tax. between 2000 and 2017. According to the upper boundaries (i.e. section 3.4) of the analysis, the AESN and the Seine-Maritime department were the two main public funders with an investment of $276.7 \mathrm{M} €$ exc. tax. (67.5\%) and 117.3 M€ (28.6\%) respectively. They supported 2699 and 1236 projects, respectively. Between 2003 and 2017, the Eure department invested 8.4 M€ (2.1\%) for 70 projects. The CHRN invested 7.6 M€ (1.8\%) between 2001 and 2009 for 302 projects. The largest expense is for hard hydraulic infrastructures (i.e. dam and retention pond) with a volume of investment ranging from 106.3 to $188.8 \mathrm{M} €$ exc. tax. This volume of investment mainly includes rehabilitation/building of infrastructures, feasibility studies, and exceptional maintenance (mainly dredging) due to exceptional rainfall events. Total investment for soft hydraulic infrastructures (i.e. fascines, hedges, grass strips, etc.) is much lower and ranged from 25.3 to $27.8 \mathrm{M} €$ exc. tax. The volume of investment for hydraulic infrastructures for which the type is unspecified counts for 8.2 to $10 \mathrm{M} €$ exc. tax. The total investment for hydraulic infrastructures reached $226.8 \mathrm{M} €$ exc. tax., almost $56 \%$ of the overall investment. Drinking water equipment, for potabilization and quantitative management, represents a volume of investment of 47.1 and $39.3 \mathrm{M} €$ exc. tax., or $21 \%$ of the overall investment. The Seine-Maritime and Eure department have almost invested the same financial volume, respectively 45 and $40 \mathrm{M} €$ exc. tax. These categories mainly include water quality monitoring, analysis of water supply and treatment installations, building/rehabilitation of water treatment unit, interconnections, and instrumentation of water treatment unit. Global studies (storm water management schemes, water development and 
management plan, environmental impact assessment, water legislation dossier, research programs,

305 etc.) and animation (agricultural outreach, water resource management, watershed management,

306 etc.) accounts respectively for 8.5\% (25-35 M€ exc. tax.) and 10.3\% (M€ 29-42 M€ exc. tax.) of the overall investment. Management of sinkholes and vulnerability to flooding represent a much smaller portion of total expenditure, respectively 11.5-12 M€ (2.9\%) and 7.3 M€ exc. tax. (1.8\%). 


\begin{tabular}{|c|c|c|c|c|}
\hline \multirow{3}{*}{ Category } & \multirow[t]{3}{*}{ Sub-category } & \multicolumn{3}{|c|}{ Volume of investment ( $€$ exc. tax) } \\
\hline & & \multirow[t]{2}{*}{ Eure department } & \multicolumn{2}{|c|}{ Seine-Maritime department } \\
\hline & & & Lower boundary & Upper boundary \\
\hline Global studies & Global studies & 6515314 & 18048495 & 28143928 \\
\hline Animation & Animation & 6478008 & 23031869 & 35879021 \\
\hline \multirow[t]{2}{*}{ Vulnerability to flooding } & Studies & 57400 & 1586792 & 1738416 \\
\hline & Rehabilitation/building & 0 & 5457064 & 5559564 \\
\hline \multirow[t]{2}{*}{ Management of sinkholes } & Studies & 2333858 & 3719609 & 4213821 \\
\hline & Rehabilitation/building & 950071 & 4767643 & 4774946 \\
\hline \multirow[t]{2}{*}{ Water potabilization } & Studies & 2014597 & 791990 & 791990 \\
\hline & Rehabilitation/building & 20716322 & 23546127 & 23546127 \\
\hline \multirow{2}{*}{$\begin{array}{l}\text { Drinking water quantitative } \\
\text { management }\end{array}$} & Studies & 3923934 & 2524854 & 2524854 \\
\hline & Rehabilitation/building & 13893859 & 19027472 & 19027472 \\
\hline \multirow[t]{3}{*}{ Soft erosion control measure } & Exceptional maintenance & 5535 & 260035 & 270345 \\
\hline & Studies & 983186 & 2680997 & 3461770 \\
\hline & Rehabilitation/building & 4810651 & 16491567 & 18216642 \\
\hline \multirow[t]{3}{*}{ Hard erosion control measure } & Exceptional maintenance & 0 & 3006151 & 3531034 \\
\hline & Studies & 1692794 & 12042289 & 18891838 \\
\hline & Rehabilitation/building & 6431263 & 83209869 & 158323882 \\
\hline \multirow{3}{*}{$\begin{array}{l}\text { Unspecified erosion control } \\
\text { measure }\end{array}$} & Studies & 1260881 & 1117648 & 1993892 \\
\hline & Rehabilitation/building & 5105397 & 806304 & 1495351 \\
\hline & Total (€ exc. tax.) & 77173070 & 222116775 & 332384893 \\
\hline
\end{tabular}


Evaluation of annual maintenance cost for erosion control measures was based on literature

review (Table 3). The reference values were chosen based on the reliability of the source and the localization of the study. When different sources were available, an average value was defined. Attention had also been paid to the expression units to allow the correspondence with the Castor database. Considering that the field operators seemed to perceive price stability since 2005, we considered in first attempt that our reference values could be expressed in $€_{2018}$. For fascines, hedges, ditches, and embankments the annual maintenance cost ranged from 1 to $6.5 €_{2018}$ exc. tax. $\mathrm{Im}^{-1}$. The maintenance actions are mainly linked to mowing, or trimming/coppicing. The annual maintenance cost for a pond was fixed regardless of the size and set to $230 €_{2018}$. This cost referred to mowing action, considering that costs of cleaning and rehabilitating (around $10 \mathrm{k} € /$ pond) were included in the overall public investments in the previous section. The annual maintenance cost for grass strip and leach field were set respectively to 889 and $460 €$ exc. tax. ha-1 ${ }^{-1}$ Grass strips are specific, and the maintenance cost consist in financial compensation for the maintenance of the area and crop losses. Finally, annual maintenance costs for dam and retention pond reached $6,880 €$ unit $^{-1}$ considering feedbacks from the catchment stakeholders (LHSM). The reference maintenance costs applied to the erosion control measures listed in the two studied departments led to a total maintenance cost of $76 \mathrm{M} €_{2018}$ exc. tax. (Table 4). The overall maintenance cost was mainly explained by operations on hard erosion control measures, that required costly civil engineering operations (cleaning) and dedicated monitoring teams. This type of infrastructure had been favored during the last twenty years with the aim of reducing the vulnerability to flooding. Hard infrastructures cost reached $66.6 \mathrm{M} €_{2018}$ exc. tax. since the beginning, or $88.7 \%$ of the volume of the overall maintenance cost. For soft infrastructures, the cumulative 206 $\mathrm{km}$ of hedge represented the highest maintenance cost, estimated to $2.6 \mathrm{M}_{2018}$ exc. tax. (3.45\% of 334 the overall maintenance cost). Even with a low spatial extent, grass strips and leach fields were expensive to maintain with a global cost of $1.9 \mathrm{M} €(2.5 \%)$. Ponds have a high storage capacity (1.1 $\mathrm{Mm}^{3}$ ) for a low maintenance a cost (1.7 M€; $\left.2.3 \%\right)$. According to the results, we observed that the 
global annual maintenance cost of erosion control measures in the Seine-Maritime department is

338 higher by a factor 10 than in the Eure department.

Table 3: Synthesis of annual maintenance costs $\left(\epsilon_{2018}\right.$ exc. Tax.) for each type of erosion control measure considered in this study.

\begin{tabular}{|c|c|c|c|}
\hline $\begin{array}{l}\text { Erosion control } \\
\text { measure }\end{array}$ & Maintenance type & $\begin{array}{l}\text { Annual maintenance } \\
\text { cost }\left(€_{2018} \text { exc. tax. }\right)\end{array}$ & Source \\
\hline Dam/retention pond & $\begin{array}{l}\text { Maintenance of } \\
\text { parkland, fences, } \\
\text { monitoring team, civil } \\
\text { engineering }\end{array}$ & 6880 unit $^{-1}$ & LHSM, pers. com. \\
\hline Grass strip & $\begin{array}{l}\text { Agri-environment } \\
\text { payment: annual loss } \\
\text { in gross margin + grass } \\
\text { maintenance }\end{array}$ & $889 \mathrm{ha}^{-1}$ & $\begin{array}{l}\text { CA Seine-Maritime } \\
\text { (2019) }\end{array}$ \\
\hline Fascine & $\begin{array}{l}\text { Trimming, weeding, } \\
\text { bundle reloading }\end{array}$ & $3 \mathrm{Im}^{-1}$ & AREAS (2011) \\
\hline Hedge & $\begin{array}{l}\text { Coppicing, trimming, } \\
\text { weeding }\end{array}$ & $2 \mathrm{Im}^{1}$ & $\begin{array}{l}\text { AREAS (2011); LIOSE } \\
\text { (2018) }\end{array}$ \\
\hline Pond & Mowing & 230 unit $^{-1}$ & Ramaekers (2018) \\
\hline Embankment & Mowing & $6,5 \mathrm{Im}^{-1}$ & ZH29 (2012) \\
\hline Ditch & Mowing, dredging & $1 \mathrm{Im}^{-1}$ & $\begin{array}{l}\text { CA Hauts-de-France } \\
\text { (2018) }\end{array}$ \\
\hline Leach field & Mowing & $460 \mathrm{ha}^{-1}$ & $\begin{array}{l}\text { CA Hauts-de-France } \\
\text { (2018) }\end{array}$ \\
\hline
\end{tabular}

Table 4: Overall volume of maintenance costs $\left(€_{2018}\right.$ exc. tax.) considering all different types of erosion control measures in the Seine-Maritime and Eure department.

\begin{tabular}{|l|r|r|}
\hline & Eure & \multicolumn{1}{|c|}{ Seine-Maritime } \\
\hline Dam/retention pond & 6121885 & 60545931 \\
\hline Grass strip & 104413 & 537386 \\
\hline Fascine & 9416 & 358948 \\
\hline Hedge & 50005 & 2577542 \\
\hline Pond & 91883 & 1689474 \\
\hline Embankment & 530823 & 1263299 \\
\hline Ditch & 91104 & $\mathbf{7 7 6 2 4 7}$ \\
\hline Leach field & 12485 & 1256026 \\
\hline Total (€ exc. tax) & $\mathbf{7 0 1 2 ~ 0 1 7}$ & $\mathbf{6 9 0 0 4 8 5 7}$ \\
\hline $\begin{array}{l}\text { 2018 annual maintenance cost } \\
\text { (€ exc. tax./yr) }\end{array}$ & $\mathbf{6 1 9 7 9 5}$ & $\mathbf{5 8 1 0 4 3 5}$ \\
\hline
\end{tabular}




\subsection{Off-site social damage cost}

\subsubsection{Insured assets}

The off-site social damages associated to flooding, runoff and mudflows were subject to 1019 CatNat decrees between 1998 and 2016 in the two cited departments induced by 65 heavy rainfall events that totalized 21497 claims. The sum of the initial costs provided by the insurance cedants amount to 44.5 M€ (Fig. 4). Considering the extrapolation of cases and number of claims for each financial year, the sum of the extrapolated costs raised to $150.7 \mathrm{M} €$. Considering hypothesis for uninsured properties (see section 3.2), the assessment of actual damage reached 226 M€. The temporal evolution of costs showed that most events occurred between 1998 and 2003. In December 1999, 505 municipalities experienced disasters in the two departments for a real cost of 53 M€. Spring storms also caused significant damages in May 2000 and June 2003, where 139 municipalities were affected, and a real cost of damages estimated to 35 and $70 \mathrm{M} €$. For the event of June 2003, the cost for the town of Le Havre alone was estimated to $59 \mathrm{M} €$ (caused rather by urban runoff). The total costs of damages to individuals were estimated to $153.1 \mathrm{M} €$ (Table 4). The total cost of damages to companies was lower and reached 72.9 M€ in the two departments. The damages were significantly higher in the Seine-Maritime than in the Eure department, with respectively 195 and 31 M€ in cumulative damage costs. However, we observed that the median real cost to professionals, per CatNat decree or per event, was higher in the Eure than in the Seine-Maritime department. The median cost per municipality, or per year and per municipality, for professionals was roughly equivalent in the two territories. We also observed a greater dispersion of the values over the Seine-Maritime territory. For example, even if the median real cost per event for professionals was lower in Seine-Maritime than in Eure (57.7 against $82.4 \mathrm{k} €$ ), the standard deviation was much greater (3.9 M€ compared to $909 \mathrm{k} €$ ). The real cost of damages to individuals was generally higher in Seine-Maritime than in the Eure, whatever the indicator chosen, and here too the standard deviation was much higher. 


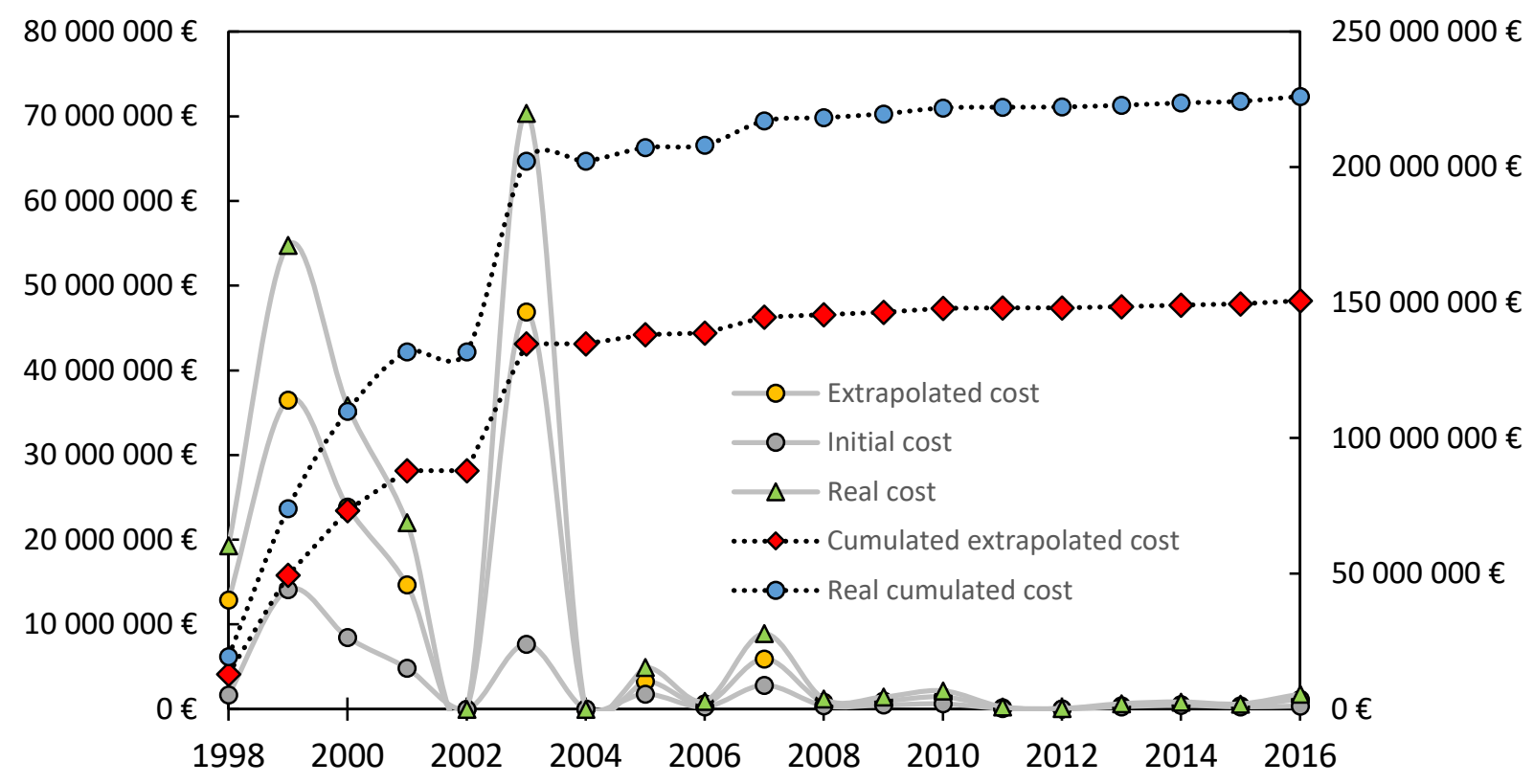

Figure 3: Temporal evolution of social damage costs induced by flooding and mudflows and listed by the CCR in the SeineMaritime and Eure department (1998-2016).

Table 5: Economic indicators for individuals and companies of social damage costs induced by flooding and mudflows and listed by the CCR in the Seine-Maritime and Eure department (1998-2016).

\begin{tabular}{|c|c|c|c|c|}
\hline & \multicolumn{2}{|c|}{ Seine-Maritime } & \multicolumn{2}{|c|}{ Eure } \\
\hline & Individuals & Companies & Individuals & Companies \\
\hline $\begin{array}{l}\text { Median per CatNat } \\
\text { decree }(k €)\end{array}$ & $15.1(\sigma=1853)$ & $17.7(\sigma=947)$ & $10.2(\sigma=314)$ & $20(\sigma=377)$ \\
\hline $\begin{array}{l}\text { Median per event } \\
(k €)\end{array}$ & $56.5(\sigma=7860)$ & $57.7(\sigma=3937)$ & $\begin{array}{r}59.9(\sigma=1 \\
153)\end{array}$ & $82.4(\sigma=909)$ \\
\hline $\begin{array}{l}\text { Median per } \\
\text { municipalities (k€; } \\
1998-2016)\end{array}$ & $28.8(\sigma=2610)$ & $24.5(\sigma=1327)$ & $13.3(\sigma=579)$ & $21.7(\sigma=702)$ \\
\hline $\begin{array}{l}\text { Median per } \\
\text { municipalities per } \\
\text { year }(k €)\end{array}$ & $18.9(\sigma=1959)$ & $22.2(\sigma=1036)$ & $9.9(\sigma=442)$ & $21.4(\sigma=554)$ \\
\hline $\begin{array}{l}\text { Total (M€; 1998- } \\
\text { 2016) }\end{array}$ & 133.1 & 62.2 & 20 & 10.6 \\
\hline
\end{tabular}

\subsubsection{Transport infrastructures}

The database provided by the French railway company reported 36 incidents between 2012 and 2018, including 13 mudflows, 4 landslides, and 19 floods. The economical cost supported by the company and linked to these incidents reached $639 \mathrm{k} €$ exc. tax (Table 6). The amount of damage per incident varies widely, from a few hundred euros to $145 \mathrm{k} €$. There is also high inter-annual variability with two significant years as 2013 and 2018 with a total cost of damages reaching 303 and $228 \mathrm{k} €$ 
respectively. Flood-type incidents accounts for $494 \mathrm{k€}$ exc. tax. over the studied period, followed by landslides (67.5 k€), and mudflows (77.2 k€).

Damage costs induced by flooding, mudflow, and landslides to roads were provided by the two departmental road services (Table 6). Data provided by the Eure departmental road service suggested a total damage cost of $1.1 \mathrm{M} €$ between 2014 and 2020. This cost included the diagnosis and filling of underground cavities, road cleaning and repairs, and the dredging of engineering structures. We observed a significant annual variability with an annual total damage cost ranging from 35 to $316 \mathrm{k} €$. The mean annual damage cost supported by the Eure departmental road service was estimated to $164.8 \mathrm{k} €$ exc. tax. The total damage cost was higher in the Seine-Maritime for a shorter period and estimated to 3.9 M€ between 2015 and 2018. This cost included the dredging of engineering structures that was subcontracted, road cleaning and repairs. The costs were more constant over time, and the mean annual damage cost supported by the Seine-Maritime departmental road service was estimated to $972 k €$ exc. tax.

These costs remained low at the scale of the studied region (i.e. Upper-Normandy region; 12 $\left.318 \mathrm{~km}^{2}\right)$. However, it is well known that linear transports networks are very sensitive to runoff hazards in this region (Lagadec et al., 2016b, 2018; Braud et al., 2020) that can directly damage railway track or electric installations, roads, and induced indirect costs such as temporary traffic stoppage. In this study, the economic cost of erosion and runoff on the railway network and departmental road is probably underestimated and highlighted a lack of sufficient and available data. 
Table 6: Economic indicators for social damage costs induced by flooding, mudflows, landslides and listed by the departmental road services in the Seine-Maritime and Eure department (1998-2016). The symbol (*) indicates that no data were available.

\begin{tabular}{|c|c|c|c|c|c|c|c|c|}
\hline \multirow[b]{3}{*}{ Year } & \multicolumn{6}{|c|}{ French railway company } & \multirow{3}{*}{$\begin{array}{l}\text { Eure departmental } \\
\text { road service } \\
\text { Diagnosis and filling of } \\
\text { underground cavities, } \\
\text { road cleaning and } \\
\text { repairs, dredging of } \\
\text { engineering structures }\end{array}$} & $\begin{array}{l}\text { Seine-Maritime departmental } \\
\text { road service }\end{array}$ \\
\hline & \multicolumn{3}{|c|}{ Eure } & \multicolumn{3}{|c|}{ Seine-Maritime } & & \\
\hline & Mudflow & Landslide & Flooding & Mudflow & Landslide & Flooding & & $\begin{array}{l}\text { Dredging subcontracted to } \\
\text { companies, road cleaning and } \\
\text { repairs }\end{array}$ \\
\hline 2012 & 0 & 0 & 0 & 39123 & 5606 & 24469 & $*$ & * \\
\hline 2013 & 0 & 14223 & 0 & 3132 & 0 & 286562 & $*$ & * \\
\hline 2014 & 0 & 0 & 0 & 6547 & 0 & 4376 & 38444 & * \\
\hline 2015 & 0 & 0 & 0 & 595 & 0 & 0 & 316653 & 873000 \\
\hline 2016 & 0 & 0 & 0 & 15650 & 0 & 0 & 160629 & 1020600 \\
\hline 2017 & 0 & 0 & 0 & 8225 & 0 & 1590 & 35626 & 873000 \\
\hline 2018 & 997 & 0 & 9509 & 2887 & 47747 & 167610 & 145476 & 1123000 \\
\hline 2019 & $*$ & $*$ & $*$ & $*$ & $*$ & $*$ & 246958 & $*$ \\
\hline 2020 & $*$ & $*$ & $*$ & $*$ & $*$ & $*$ & 209844 & $*$ \\
\hline $\begin{array}{l}\text { Total cost }\left(\begin{array}{ll}€ & \text { exc. } \\
\text { Tax. })\end{array}\right. \\
\end{array}$ & \multicolumn{3}{|c|}{24729} & \multicolumn{3}{|c|}{614119} & 1153630 & 3889600 \\
\hline $\begin{array}{l}\text { Mean annual cost ( } € \\
\text { exc. tax) }\end{array}$ & 110 & 1580 & 1057 & 8462 & 5928 & 53845 & 164804 & 972400 \\
\hline
\end{tabular}


The evaluation was based on the 407 prohibitions of clean water drinking induced by an 405 excessive turbidity at multiple water treatment plant and recorded in the Eure $(n=88)$ and Seine406 Maritime department $(n=319)$ between 1992 and 2018. Over the entire period, $1.6 M$ inhabitants were impacted, and the total damage cost reached 4.7 M€ exc. tax. The cumulated damage cost between 1992 and 2018 reached 3.8 M€ in the Seine-Maritime department and 0.9 M€ in the Eure department. The financial volumes are distributed as follow: distribution of bottled water for $2.5 \mathrm{M€}$ (53.2\%); distribution logistics for $1.2 \mathrm{M} €$ (25.5\%); and the public alert management for $1 \mathrm{M} €$ (21.3\%). The mean cost of an event was slightly higher in the Seine-Maritime department (12 k€) than in the Eure department $(10 \mathrm{k} €)$. The mean duration of a prohibition of clean water drinking event lasted 413 longer in the Eure department (17.6 days) than in the Seine-Maritime department (10.5 days), but the 414 mean population impacted was lower (2 941 versus 4 147). Despite substantial investments since the 415 last decades to reduce erosion and runoff on the studied areas, we observed that some drinking water companies are still regularly impacted. 


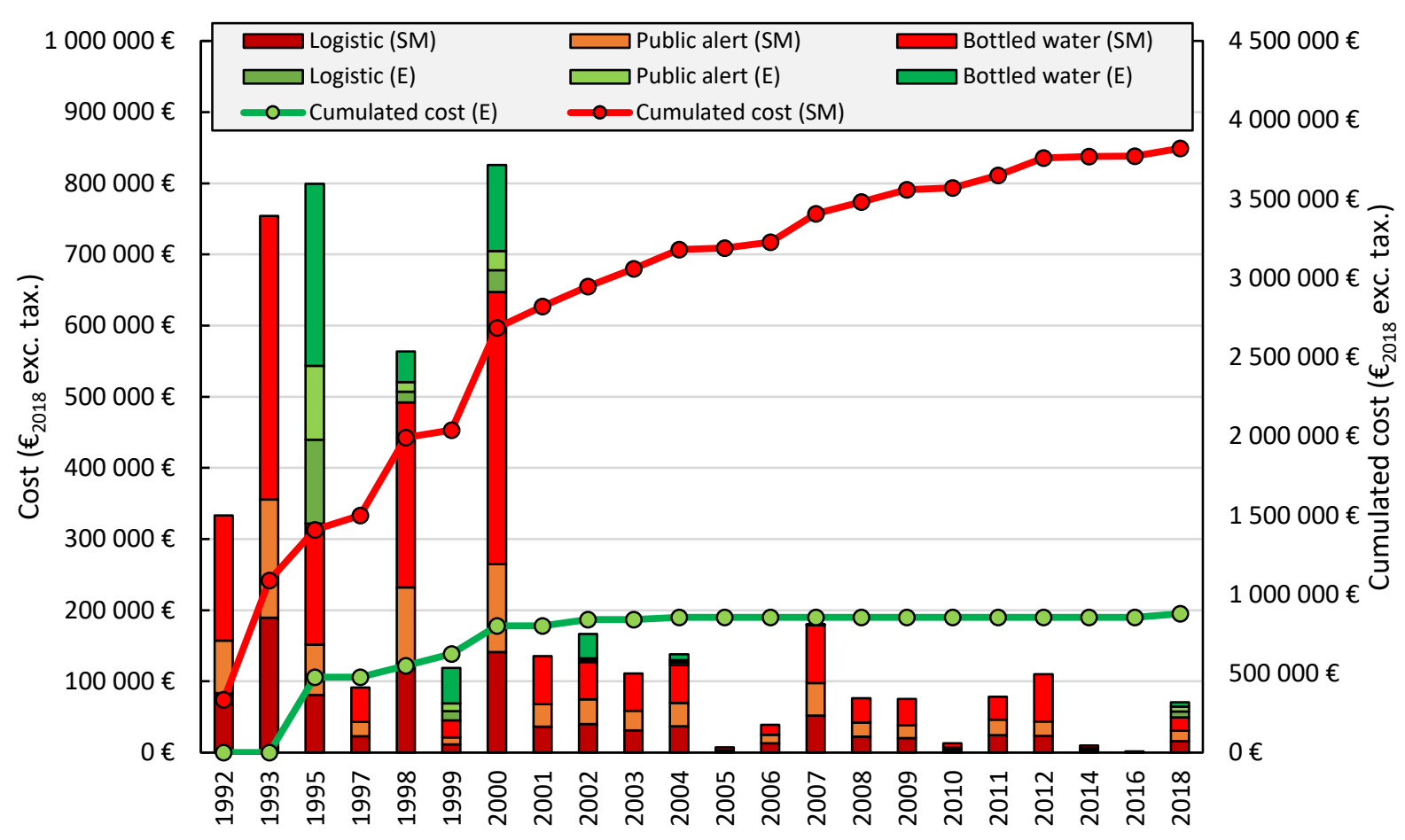

Figure 4: Temporal variability of indirect damage costs induced by turbidity at water treatment plant in the Seine-Maritime and Eure department. The damage costs included the distribution logistic, the bottled water dispensing, and the public alert (SM = Seine-Maritime; E = Eure). 


\subsection{Overview}

422

423

424

425

426

427

Our analysis suggested that main off-site impacts of erosion and runoff can led to significant expenditures for public authorities. In the two studied areas (i.e. Seine-Maritime and Eure), located in the northwestern European loess belt, the total damage costs induced by the main off-site impacts of erosion and runoff ranged from 611 to $721 \mathrm{M} €$ over the last 25 years. The Seine-Maritime was the most impacted area and the total damage cost ranged from 494 to $604 \mathrm{M} €$. In the Eure, the total damage cost reached $116 \mathrm{M} €$. For both areas, off-site avoidance damage costs represented 65 to $72 \%$ of the total financial expenditure and off-site social damage costs represented 28 to $35 \%$. For example, and on average, $1 \%$ of the Seine-Maritime's department annual budget was spent each year to reduce erosion and runoff off-site impacts.

The projection of these costs over time (1995-2017) in relation to the demography showed us that the mean cost per capita for the Seine-Maritime reached $21.6 € \mathrm{yr}^{-1} \mathrm{cap}^{-1}$ and was higher than in the Eure for which it was evaluated to $9.1 € \mathrm{yr}^{-1} \operatorname{cap}^{-1}$ (Fig. 6). Even if few erosion and runoff studies focusing on the economical dimension exist (Panagos et al., 2018), we found that some attempts have been proposed in the northwestern European loess belt to quantify the cost of the erosion and runoff off-site impacts. In Flanders in Belgium, Verstraeten et al. (2006) suggested that the cost of erosion off-site impacts reached 55 to $90 \mathrm{M} € \mathrm{yr}^{-1}$. The studied off-site impacts were damages from muddy floods to private properties, river, and pond sedimentation. In relation to the demography the mean cost per capita can ranged from 9 to $14.8 € \mathrm{yr}^{-1}$ cap $^{-1}$. In Alsace in France, Cerdan et al. (2009) quantified the cost of direct and indirect damages induced by muddy floods on private properties, industries, and communities between 1984 and 2006. The results suggested that the mean cost per capita reached 26 $€ \mathrm{yr}^{-1}$ cap $^{-1}$. In South Limburg in Netherlands, the mean cost per capita due to erosion off-site impacts reached $1.04 € \mathrm{yr}^{-1} \operatorname{cap}^{-1}$ (Van Eck (1995) in Kwaad et al. (2006)). Even if the economic cost of off-site impacts can be different due to the availability of the data, one can observed that these costs remain in the same order of magnitude in the northwestern European loess belt. 
While these costs are significant, unfortunately they are not exhaustive and represent only the

447 "tip of the iceberg". In this study, we addressed a detailed and accurate assessment of main off-site

448 costs associated with soil erosion in northwestern France, which could be extrapolated in other areas

449 of the northwestern European loess belt. Soil erosion community could go further using these results

450 and those found in the literature and reported in table 7. But the challenge would be ambitious trying

451 to quantify all existing off-site impacts of erosion and runoff. The quantification of off-site costs in

452 some areas can also be difficult if the data are not centralized. Moreover, there is still different types

453 of off-site impacts for which related costs are still unknown (i.e. psychological damages, loss of value

454 of a flooded habitat, patrimonial values of preserving soils) and more research are therefore required. 

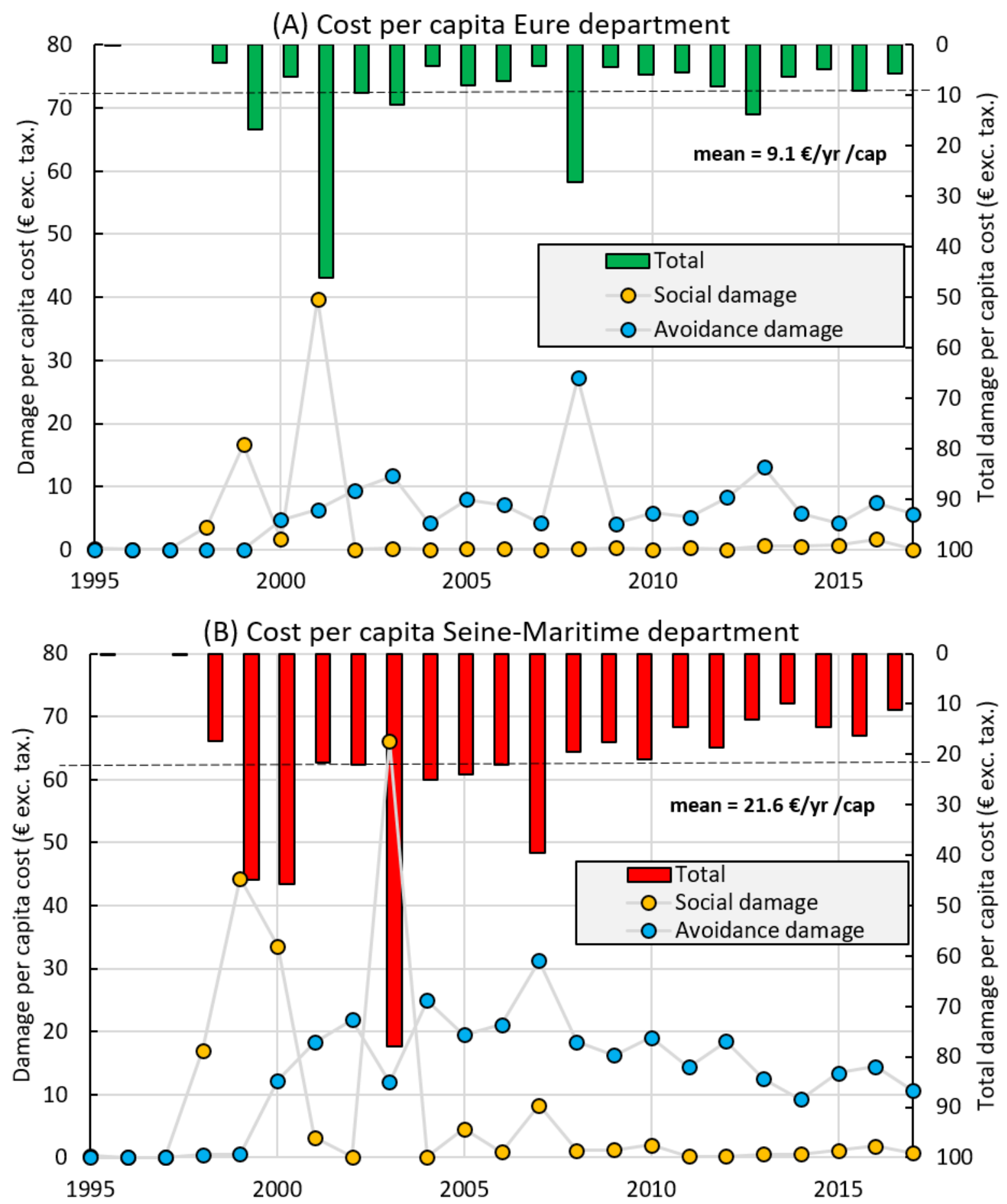

Figure 5: Temporal evolution of cost per capita induced by erosion and runoff main off-site impacts for the two studied areas (Seine-Maritime and Eure). 


\begin{tabular}{|c|c|c|c|}
\hline Service / function & Soil erosion and runoff impacts & Evaluated in this study? & Evaluated in the literature \\
\hline $\begin{array}{l}\text { Support of food, fuel and fibre } \\
\text { production }\end{array}$ & Reduced crop productivity & No & $\begin{array}{l}\text { The annual loss of crop productivity is } \\
\text { estimated to be around } 1.2 \text { billion } € \text { in } \\
\text { Europe (Panagos et al., 2018); } 3.55 \mathrm{f} \text { per } \\
\text { ha (Posthumus et al., 2015) }\end{array}$ \\
\hline Drainage/discharge of water & Siltation of dams and watercourses & No & $\begin{array}{l}0.85 \$ \text { per ton of sediment (Moore et al., } \\
\text { 1987); } 1.29 \$ \text { per ton of sediment } \\
\text { (Macgregor, 1988); } 16.62 f \text { per ha } \\
\text { (Posthumus et al., 2015) }\end{array}$ \\
\hline Infrastructures & Interruption of services, transports & No & $\begin{array}{l}\text { Median indirect cost of a } \\
\text { hydrometeorological event on the } \\
\text { European railway network estimated to } 1 \\
\text { M€ (Maurer et al., 2012) }\end{array}$ \\
\hline Infrastructures & Damages to road & $\begin{array}{l}0.23-0.77 € \mathrm{yr}^{-1} \mathrm{cap}^{-1} \text { in } \\
\text { average }\end{array}$ & $\begin{array}{l}2.65 £ \text { per ha (Posthumus et al., 2015); } \\
14 \text { k€ - } 300 \text { k€ per event and per } \\
\text { municipality (Evrard et al., 2007) }\end{array}$ \\
\hline Infrastructures & Damages to railway & $\begin{array}{l}0.02-0.07 € \mathrm{yr}^{-1} \operatorname{cap}^{-1} \text { in } \\
\text { average }\end{array}$ & $\begin{array}{l}\text { Median direct cost of a } \\
\text { hydrometeorological event on the } \\
\text { European railway network estimated to } \\
\text { 1.69 M€ (Maurer et al., 2012) }\end{array}$ \\
\hline Infrastructures & Cleaning operations (roads and streets) & No & $\begin{array}{l}500 €-11 \text { k€ per event (Evrard et al., } \\
2007)\end{array}$ \\
\hline Infrastructures & $\begin{array}{l}\text { Damages to private properties and } \\
\text { companies }\end{array}$ & $\begin{array}{l}3.4-9.6 € \mathrm{yr}^{-1} \mathrm{cap}^{-1} \text { in } \\
\text { average }\end{array}$ & $\begin{array}{l}10-30 € \text { ha }^{-1} \mathrm{yr}^{-1} \text { at the level of a } \\
\text { municipality in Flanders in Belgium } \\
\text { (Boardman et al., 2006); } 5.5 € \text { ha }^{-1} \mathrm{yr}^{-1} \text { for } \\
\text { South Limburg in Netherlands (Schouten et } \\
\text { al., 1985) }\end{array}$ \\
\hline Infrastructures & Fire brigade interventions & No & $\begin{array}{l}2.25 \mathrm{k} €-25 \mathrm{k} € \text { per event (Evrard et al., } \\
2007)\end{array}$ \\
\hline Provision of drinking water & $\begin{array}{l}\text { Water treatment cost to remove sediments } \\
\text { and pollutants }\end{array}$ & No & $\begin{array}{l}0.32 \$ \text { per ton of sediment delivered } \\
\text { (Forster et al., 1987); } 5.27 £ \text { per ha }\end{array}$ \\
\hline
\end{tabular}




\begin{tabular}{|c|c|c|c|}
\hline & & & $\begin{array}{l}\text { (Posthumus et al., 2015); 2.17€ per kg of } \\
\text { sediment (Patault et al., 2020) }\end{array}$ \\
\hline Business interruption & Delayed production of goods and services & No & \multirow{9}{*}{$\begin{array}{c}\text { To the best of our knowledge, there was } \\
\text { no scientific literature dealing with those } \\
\text { items }\end{array}$} \\
\hline Mitigation measures & Maintenance of erosion control measures & $\begin{array}{l}1-4.6 € \mathrm{yr}^{-1} \text { cap }^{-1} \text { based } \\
\text { on the inventory for } \\
2018\end{array}$ & \\
\hline Mitigation measures & Building of erosion control measures & \multirow{6}{*}{$7.3-14 € \mathrm{yr}^{-1}$ cap $^{-1}$} & \\
\hline Mitigation measures & $\begin{array}{l}\text { Animation (agricultural outreach, water } \\
\text { resource management, watershed } \\
\text { management) }\end{array}$ & & \\
\hline Mitigation measures & Drinking water equipment and potabilization & & \\
\hline Mitigation measures & $\begin{array}{l}\text { Global studies (environmental impact } \\
\text { assessment, water legislation dossier, } \\
\text { research programs, etc.) }\end{array}$ & & \\
\hline Mitigation measures & Management of sinkholes & & \\
\hline Mitigation measures & Vulnerability to flooding & & \\
\hline Provision of drinking water & Drinking water prohibition & $\begin{array}{l}0.06-0.11 € \mathrm{yr}^{-1} \text { cap }^{-1} \text { in } \\
\text { average }\end{array}$ & \\
\hline Health & $\begin{array}{l}\text { Human lives lost through floods and } \\
\text { mudflows }\end{array}$ & No & $\begin{array}{l}40 \mathrm{k} \$ \text { - } 6 \mathrm{M} \$ \text {. We are aware that putting a } \\
\text { value of life can be ethically controversial. } \\
\text { For this reason, we showed a range of } \\
\text { statistical life estimates as reported by } \\
\text { Kunreuther et al. (2012). Also, as } \\
\text { suggested by May et al. (1982) when } \\
\text { intangibles are left out there is a strong } \\
\text { risk of potentially life threatening or } \\
\text { injurious action }\end{array}$ \\
\hline Health & $\begin{array}{l}\text { Anxiety and uncertainty associated with } \\
\text { floods and mudflows }\end{array}$ & No & \multirow{3}{*}{$\begin{array}{l}\text { To the best of our knowledge, there was } \\
\text { no scientific literature dealing with those } \\
\text { items }\end{array}$} \\
\hline Sustainable development & Impact on landscape values and biodiversity & No & \\
\hline Sustainable development & $\begin{array}{l}\text { Patrimonial value of preserving soil for } \\
\text { future generations }\end{array}$ & No & \\
\hline
\end{tabular}




\section{Conclusions}

In this study, the main off-site economic costs induced by erosion and runoff processes were assessed for two areas of the northwestern European loess belt located in Normandy in France (Eure and Seine-Maritime areas). We analyzed avoidance and social damage costs over the last 25 years through databases provided by regional and/or local authorities and available scientific literature. The results suggested that between 2000 and 2017 the overall volume of public investments ranged from 300 to $410 \mathrm{M} €$ to avoid erosion and runoff impacts. In addition, $76 \mathrm{M} €$ were spent for the maintenance of the erosion and runoff control measures. Between 1998 and 2016, 65 heavy rainfall events induced erosion and runoff impacts which led to 21497 claims to insurances. The total damage costs reached 226 M€. Between 2012 and 2018, 36 minor incidents were reported on the railway infrastructures. The economical cost linked to these incidents reached $639 \mathrm{k} €$. The damage costs supported by the two departmental road services were evaluated to $5 \mathrm{M} €$ between 2014 and 2020. The prohibition of drinking water in response to high level of turbidity in raw water induced by runoff and erosion led to a significant expense of $4.7 \mathrm{M} €$ for drinking water suppliers. Finally, we evaluated the total damage off-site costs induced by erosion and runoff impacts to $611-721 \mathrm{M€}$ over the last 25 years. Thus, the mean cost per capita ranged from 9.1 to $21.6 € \mathrm{yr}^{-1} \mathrm{cap}^{-1}$ for the Eure and the Seine-Maritime area, respectively. Here we provided a detailed estimation of the annual costs induced by erosion and runoff off-site impacts on the studied areas, which can be extrapolated to other areas in the northwestern European loess belt. However, we are aware that this is a minimum threshold considering that some off-site impacts are still non-evaluable due to a lack of available data or knowledge. We can suggest performing additional research to provide a full picture of all off-site economic costs induced by erosion and runoff impacts. 


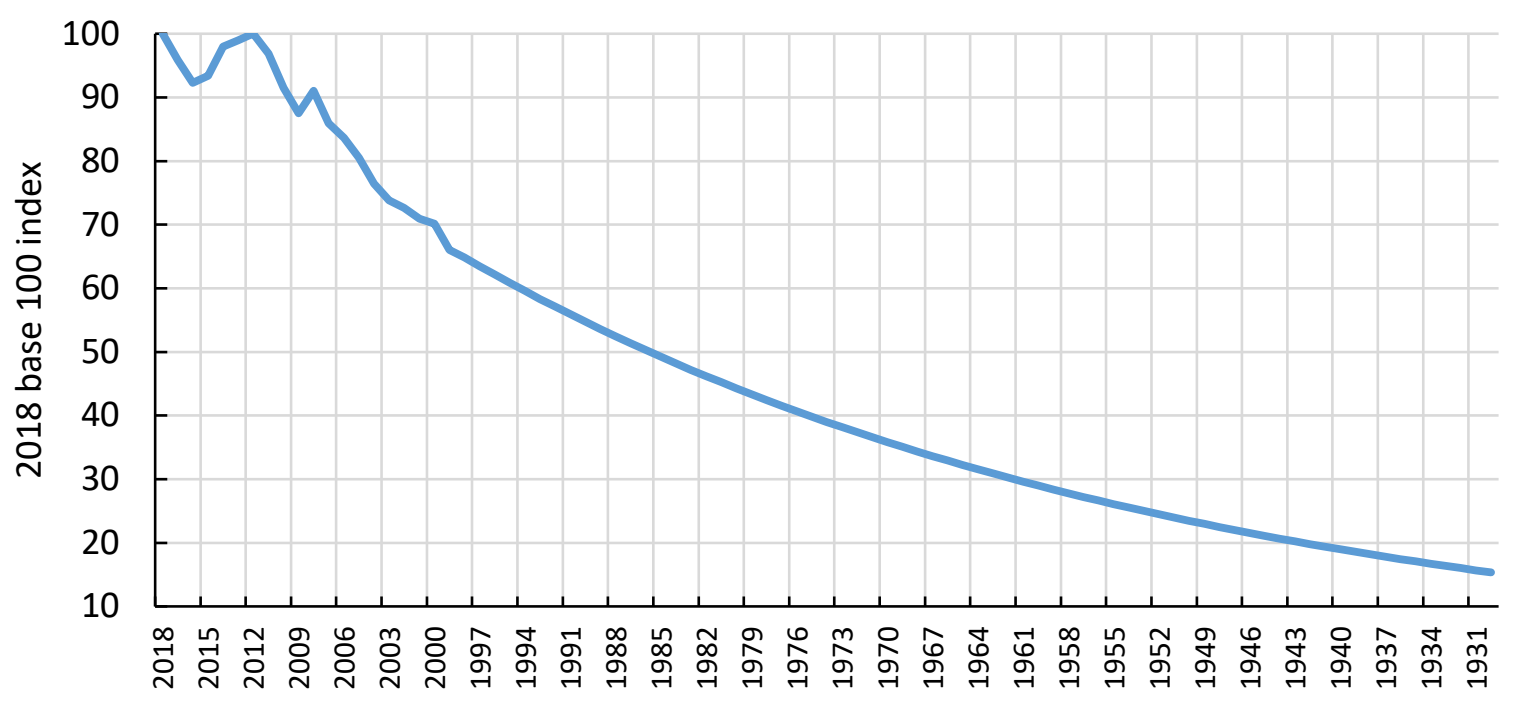

\section{Appendix B:}

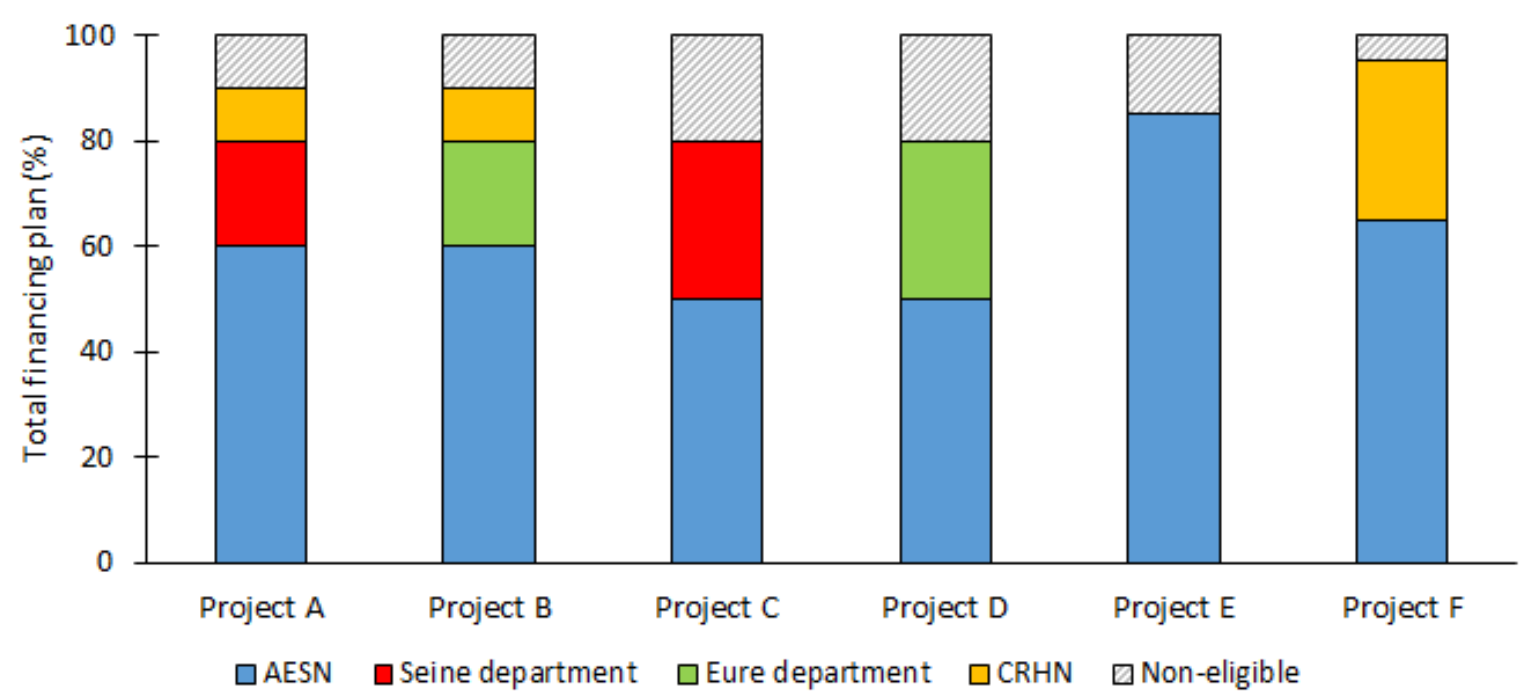




\section{Author contribution}

Conceptualization JL, BL, JFO, OC; Formal analysis EP, JL, JBR, AS; Funding acquisition BL, OC, JFO; Investigation EP, JL; Methodology EP, JL, AS; Project administration MF, BL, OC, JFO; Supervision ML, BL, OC, JFO; Validation EP, JL, VL, MF, OC; Visualization EP; Writing - original draft EP, VL, OC

\section{Acknowledgments}

This study is based on research undertaken as part of EVAPORE project "EVAluation de l'efficacité des POlitiques publiques pour les actions visant à REduire les impacts du ruissellement" to evaluate efficiency of public policy to reduce erosion and runoff impacts. Authors are thankful to the University of Rouen, AREAS, BRGM, and AESN who co-founded this project, and all institutions who provided access to their data (AESN, SNCF, ARS27/76, Seine department, Eure department, CRHN, (CR).

\section{References}

[1] AREAS (2011). Caractérisation de l'efficacité hydraulique des haies et des fascines. Programme de recherche 2009-2011. Association de recherche sur le Ruissellement, l'Erosion et l'Aménagement du Sol. Retrieved from. http://www.areasasso.fr/images/formations2011/Efficacite Haie Fascine Formation animateurs Dec2011\%2 $\underline{0 . p d f}$

[2] Bakker, M.M., Govers, G., Rounsevell, M.D.A. (2004). The crop productivity-erosion relationship: an analysis based on experimental work. Catena, 57(1), 55-76 pp. https://doi.org/10.1016/j.catena.2003.07.002

[3] Boardman, J., Verstraeten, G., Bielders, C. (2006). Muddy floods. In: Boardman, J., Poesen, J. (Eds.), Soil Erosion in Europe. John Wiley \& Sons, UK, 743-55pp. doi://10.1002/0470859202.ch53

[4] Boardman, J., Vandaele, K., Evans, R., Foster, I.D.L. (2019). Off-site impacts of soil erosion and runoff: Why connectivity is more important than erosion rates. Soil Use Management, 35, 245$256 \mathrm{pp}$.

[5] Braud, I., Lagadec, L-R., Moulin, L., Chazelle, B., Breil, P. (2020). A method to use proxy data of runoff-related impacts for the evaluation of a model mapping intense storm runoff hazard: application to the railway context. Nat. Hazards Earth Syst. Sci., 20, 947-966 pp.

[6] CA Seine-Maritime (2019). Indemnisations des servitudes ou conventions. Chambre d'Agriculture Seine-Maritime. Retrieved from. https://seine-maritime.chambresagriculture.fr/territoires/indemnisations/amenagements-hydrauliques/indemnisation-desservitudes-ou-conventions/

[7] CA Hauts-de-France (2018). Guide de l'érosion : lutte contre l'érosion. Chambre d'Agriculture Hauts-de-France. Retrieved from https://hautsdefrance.chambres- 
agriculture.fr/fileadmin/user upload/National/FAL commun/publications/Hauts-deFrance/guide-erosion-2018.pdf

[8] CCR (2017). Les catastrophes naturelles en France: bilan 1982-2017. Bilan du régime d'indemnisation des catastrophes naturelles depuis sa création en 1982. Retrieved from: https://catastrophes-naturelles.ccr.fr/-/les-catastrophes-naturelles-en-france-bilan-1982$\underline{2017}$

[9] Cerdan, O., Auzet, A.V., Bouzit, M., Van Dijk, P., Guyonnet, J., Moquet, J.S., Cruz-Mermy, D., Heitz, C. (2009). Enjeux économiques liés à l'aléa d'érosion des sols: étude pilote de faisabilité d'une évaluation des coûts dans une région Française (Alsace). Rapport BRGM/RP-56932-FR.

[10]Cerdan, O., Govers, G., Le Bissonnais, Y., Van Oost, K., Poesen, J., Saby, N., Gobin, A., Vacca, A., Quinton, J., Auerswald, K., Kilk, A., Kwaas, F.J.P.M., Raclot, D., Ionita, I., Rejman, J., Rousseva, S., Muxart, T., Roxo, M.J., Dostal, T. (2010). Rates and spatial variations of soil erosion in Europe: A study based on erosion plot data. Geomorphology, 122, 167-177 pp.

[11]Clark, R. (1996). Methodologies of the Economic Analysis of Soil Erosion and Conservation, CSERGE Working Paper (Vol. GEC96-13). Norwich: University of East Anglia.

[12]De la Rosa, D., Moreno, J.A., Mayol, F., Bonson, T. (2000). Assessment of soil erosion vulnerability in western Europe and potential impact on crop productivity due to loss of soil depth using the ImpelERO model. Agriculture, Ecosystems \& Environment, 81(3), 179-190 pp. https://doi.org/10.1016/S0167-8809(00)00161-4

[13]Dorren, A., Bazzofi, P., Sanchez Diaz, J., Arnoldussen, A., Barberis, R., Berényi Üveges, J., Böken, H., Castillo, V., Düwel, O., Imeson, A., Mollenhauer, K., de la Rosa, D., Prasuhn, V., Theocharopoulos, S. (2004). Working Group on Soil Erosion, Task Group III on Impacts of Soil Erosion. European Commission. Final report.

[14]El Janyani, S., Dupont, J.P., Massei, N., Slimani, S., Dörfliger, N. (2014). Hydrological role of karst in the Chalk aquifer of Upper Normandy, France. Hydrogeology Journal, 22, 663-677 pp.

[15]European Parliament (2000). Establishing a framework for community action in the field of water policy. Directive EC/2000/60, Brussels, Belgium: EU.

[16]Eurostat (2017). Socio-economic profile of Haute-Normandie. Retrieved from https://ec.europa.eu/growth/tools-databases/regional-innovation-monitor/baseprofile/haute-normandie

[17]Evans, R. (1996). Soil Erosion and its Impact in England and Wales. Friends of the Earth Trust, London.

[18]Evrard, O., Bielders, C. L., Vandaele, K., van Wesemael, B. (2007). Spatial and temporal variation of muddy floods in central Belgium, off-site impacts and potential control measures. Catena, 70, 443-454 pp.

[19]Evrard, O., Heitz, C., Liégois, M., Boardman, J., Vandaele, K., Auzet, A-V., Van Wesemael, B. (2010). A comparison of management approaches to control muddy floods in central Belgium, Northern France and Southern England. Land Degradation \& Development, 21, 322-335 pp.

[20]Evrard, O., Nord, G., Cerdan, O., Souchère, V., Le Bissonnais, Y., Bonté, P. (2010). Modelling the impact of land use change and rainfall seasonality on sediment export from an agricultural catchment of the northwestern European loess belt. Agriculture, Ecosystems and Environment, 138, 83-94 pp. doi:10.1016/j.agee.2010.04.003

[21]Food and Agriculture Organization of the United Nations (2019). Symposium Working Documents. Global Symposium on Soil Erosion, 15-17 May 2019, Rome, Italy.

[22]Forster, D.L., Bardoes, C.P., Southgate, D. (1987). Soil erosion and water treatment costs, J. Soil Water Conserv., 42(5), 367-369 pp.

[23]Fullen, M.A., Arnalds, A., Bazzoffi, P., Booth, C.A., Castillo, V., Kerstesz, A., Martin, P., Ritsema, C., Sole Benet, A., Souchère, V., Vandekerckhove, L., Verstraeten, G. (2006). Government and agency response to soil erosion risk in Europe. In: Boardman, J., Poesen, J. (Eds.), Soil Erosion in Europe. John Wiley \& Sons, UK, 805-828 pp.

[24]Görlach, B., Landgrebe-Trinkunaite, R., Interwies, E., Bouzit, M., Darmendrail, D., Rinaudo, J.D. (2004). Assessing the Economic Impacts of Soil Degradation. Volume IV: Executive Summary. 
[25]Holmes, T.P. (1988). The Offsite Impact of Soil Erosion on the Water Treatment Industry. Land Economics, 64(4), 356-366 pp.

[26]Hanin, G. (2011). Contrôles structural et hydrogéologique sur la dynamique d'un champ captant en contexte crayeux karstique et sa sensibilité aux variations du signal climatique : implications en matière de la vulnérabilité de la ressource. Thèse de doctorat. Université de Rouen, France. $320 \mathrm{p}$.

[27]INSEE (2017). Bilan démographique 2017 : la population normande stoppe sa progression. Retrieved from: https://www.insee.fr/fr/statistiques/3613257

[28]Kunreuther, H., Michel-Kerjan, E. (2012). Policy Options for Reducing losses from Natural Disasters: allocating $\$ 75$ billion. Natural Disasters, challenge paper. Copenhagen Consensus.

[29]Kwaad, F.J.P.M., de Roo, A.P.J., Jetten, V.G. (2006). The Netherlands. In: Boardman, J., Poesen, J. (Eds.), Soil Erosion in Europe. John Wiley \& Sons, UK, https://doi.org/10.1002/0470859202.ch31

[30]Lagadec, L-R., Patrice, P., Braud, I., Chazelle, B., Moulin, L., Dehotin, J., Hauchard, E., Breil, P. (2016b). Description and evaluation of a surface runoff susceptibility mapping method. Journal of Hydrology, 541(A), 495-509 pp.

[31]Lagadec, L-R., Moulin, L., Braud, I., Chazelle, B., Breil, P. (2018). A surface runoff mapping method for optimizing risk assessment on railways. Safety Science, 110, 253-267 pp.

[32]Lal, R. (2010). Soil erosion impact on agronomic productivity and environment quality. Critical reviews on plant sciences, 17(4), 319-464 pp. https://doi.org/10.1080/07352689891304249

[33]Le Bissonnais, Y., Thorette, J., Bardet, C., Daroussin, J. (2002). L'érosion hydrique des sols en France. Retrieved from http://erosion.orleans.inra.fr/rapport2002/

[34]LIOSE (2018). Etude de conception d'un plan d'hydraulique douce sur le bassin versant du Clignon amont. Phase 2: Scénarios. Retrieved from: http://www.union-dessyndicats.fr/Projetsencours/fiche/id/39

[35]Macgregor, R. (1988). The value of lost boater value use and the cost of dredging: evaluation of two aspects of sedimentation in Ohio's State Park Lakes, Ph.D. dissertation, the Ohio State University, Columbus.

[36]Magrath, W. \& Arens, P. (1989). The cost of soil erosion on Java: A natural resource accounting approach. Washington, the World Bank. 67p. (Environment Working Paper, 18)

[37]Mansotte, F. (1998). Pluviométrie et qualité des eaux d'alimentation en Seine-Maritime. Impact de 8 épisodes pluvieux de décembre 1992 à avril 1998. Préfecture du département de la Seine-Maritime. Direction Départementale des Affaires Sanitaires et Sociales. Service Santé et Environnement.

[38]Martin, P., Joannon, A., Piskiewicz, N. (2010). Temporal variability of surface runoff due to cropping systems in cultivated catchment areas: Use of the DIAR model for the assessment of environmental public policies in the Pays de Caux (France). Journal of Environmental Management, 91, 869-878 pp. doi:10.1016/j.jenvman.2009.11.003

[39]Martin, P., Ronfort, C., Laroutis, D., Souchère, V., Sebillotte, C. (2014). Cost of best management practices to combat agricultural runoff and comparison with the local populations' willingness to pay: Case of the Austreberthe watershed (Normandy, France). Land Use Policy, 38, 454-466 pp. http://dx.doi.org/10.1016/j.landusepol.2013.12.014

[40]Masséi, N., Wang, H.Q., Dupont, J.P., Rodet, J., Laignel, B. (2003). Assessment of direct transfer and resuspension of particles during turbid floods at a karstic spring. Journal of Hydrology, 275, 109-121 pp.

[41]Maurer, H., Rudzikaite, L., Kiel, J., Partzch, I., Pelikan, V., Sedlacek, N., Mitsakis, E., Stamos, I., Papanikolaou, A., Celano, M., Mezzasalma, P., Pavan, V., Alberoni, A., Genovese, E., Przyluski, V., Hallegatte, S. (2012). Weather extremes: assessment of impacts on transport systems and hazards for European regions. Hal-00803668

[42]May, W.W. (1982). \$s for lives: ethical considerations in the Use of Cost/Benefit Analysis by for-profit firms. Risk Analysis, 2(1), 35-46 pp. 
[43]Moncoulon, D., Labat, D., Ardon, J., Leblois, E., Onfroy, T. (2014). Analysis of the French insurance market exposure to floods: a stochastic model combining river overflow and surface runoff. Nat. Hazards Earth Syst. Sci., 14(9), 2469-2485 pp.

[44]Moore, W.B., McCarl, B.A. (1987). Off-site costs of soil erosion: a case study in the Willamette Valley. Western Journal of Agricultural Economics, 12(1), 42-49 pp.

[45]Nebbache, S., Feeny, V., Poudevigne, I., Alard, D. (2001). Turbidity and nitrate transfer in karstic aquifer in rural areas: the Brionne basin case-study. Journal of Environmental Management, 62, 389-398 pp.

[46]Panagos, P., Meusburger, K., Ballabio, C., Borrelli, P., Alewell, C., 2014. Soil erodibility in Europe: a high-resolution dataset based on LUCAS. Sci. Total Environ. 479e480, 189e200.

[47]Panagos, P., Standardi, G., Borrelli, P., Lugato, E., Montanarella, L., Bosello, F., 2018. Cost of agricultural productivity loss due to soil erosion in the European Union: from direct cost evaluation approaches to the use of macroeconomic models. Land Degrad. Dev. 29, 471-484. https://doi.org/10.1002/ldr.2879

[48]Patault, E., Ledun, J., Landemaine, V., Soulignac, A., Richet, J.B., Fournier, M., Rinaudo, J.D., Ouvry, J.F., Cerdan, O., Laignel, B. (2020). Evaluation de l'efficacité des politiques publiques pour les actions visant à réduire les impacts du ruissellement et de l'érosion en HauteNormandie. Rapport final. Université de Rouen Normandie - AREAS - BRGM, 356 p. Retrieved from: https://hal.archives-ouvertes.fr/hal-02958904

[49]Pimentel, D., Harvey, C., Resosudarmo, P., Sinclair, K., Kurz, D., McNair, M., Crist, S., Shpritz, L., Fitton, L., Saffouri, R., Blair, R. (1995). Environmental and economic costs of soil erosion and conservation benefits. Science, 267(5201), 1117-1123 pp. doi:10.1126/science.267.5201.1117

[50]Posthumus, H., Deeks, L.K., Rickson, R.J., Quinton, J.N. (2015). Costs and benefits of erosion control measures in the UK. Soil Use and Management, 31(1), 16-33 pp. doi:10.1111/sum.12057

[51]Pretty, J.N., Brett, C., Gee, D., Hine, R.E., Mason, C.F., Morison, J.I.L., Raven, H., Rayment, M.D., van der Bijl, G. (2000). An assessment of the total external costs of UK agriculture. Agricultural systems, 65, 113-136 pp.

[52]Ramaekers, F. (2018). Etude technico-économique sur les actions et les impacts des inondations par ruissellement en Seine-Maritime sur la période 2000-2017. Master 2 Gestion de l'environnement, parcours Gestion Durable des Hydrogéosystèmes, $81 \mathrm{p}$.

[53]Santos Telles, T., Fatima Guimaraes, M., Falci Dechen, S.C. (2011). The costs of soil erosion. Revista Brasileira de Ciencia do Solo, 35(2), 287-298 pp.

[54]Schouten, C.J., Rang, M.C., Huigen, P.M.J. (1985). Erosie en wateroverlast in Zuid-Limburg. Lanschap, 2, 118-132 pp.

[55]SIGES Seine-Normandie, 2013. Synthèse régionale Haute-Normandie. Retrieved from. http://sigessn.brgm.fr/IMG/pdf/synthese regionale hno.pdf

[56]Souadi, T., King, C., Le Bissonnais, Y. (2000). Cartographie régionale de l'aléa érosion des sols en region Haute-Normandie. BRGM/RP-50454-FR, 95p.

[57]Souchère, V., King, C., Dubreuil, N., Lecomte-Morel, V., Le Bissonnais, Y., Chalat, M. (2003). Grassland and crop trends: role of the European Union Common Agricultural Policy and consequences for runoff and soil erosion. Environmental Science \& Policy, 6, 7-16 pp. doi:10.1016/S1462-9011(02)00121-1

[58]Stevenson, M. \& Bravo, C. (2019). Advanced turbidity prediction for operational water supply planning. Decision Support Systems, 119, 72-94 pp.

[59]Valdes, D., Dupont, J.P., Massei, N., Laignel, B., Rodet, J. (2005). Analysis of karst hydrodynamics through comparison of dissolved and suspended solids' transport. C. R. Geosciences, 337, 1365-1374 pp.

[60]Valdes, D., Dupont, J.P., Massei, N., Laignel, B., Rodet, J. (2006). Investigation of karst hydrodynamics and organization using autocorrelations and T- $\Delta C$ curves. Journal of Hydrology, https://doi.org/10.1016/i.jhydrol.2006.02.030 
[61]Van Eck W, Slothouwer D, Sprik JB, IJkelenstam GFP. 1995. Erosienormeringsonderzoek ZuidLimburg. Kosten en Baten van Erosiebestrijdingsmaatregelen in Zuid-Limburg. Rapport 364.2. DLO, Staring Centrum, Wageningen.

[62]Verstraeten, G., Poesen, J., Goosens, D., Gillijns, K., Bielders, C., Gabriels, D., Ruysschaert, G., Van Den Eeckhaut, M., Vanwalleghem, T., Govers, G. (2006). Belgium. In: Boardman, J., Poesen, J. (Eds.), Soil erosion in Europe. John Wiley \& Sons, UK. https://doi.org/10.1002/0470859202.ch30

[63]ZH29 (2019). Créations de talus en limite de zones humides. Zones humides 29. Retrieved from http://www.zoneshumides29.fr/telechargement/GTAGZH Creation talus ceinture 032012. pdf 